\title{
Diversity of Ralstonia solanacearum Strains on the Andaman Islands in India
}

K. Sakthivel, R. K. Gautam, K. Kumar, and S. Dam Roy, Division of Field Crop Improvement and Protection, Central Island Agricultural Research Institute, Port Blair 744 101, Andaman and Nicobar Islands, India; A. Kumar, C. Devendrakumar, M. Vibhuti, and S. Neelam, Division of Plant Pathology, Indian Agricultural Research Institute, New Delhi 110 012, India; and B. A. Vinatzer, Department of Plant Pathology, Physiology, and Weed Science, Virginia Tech, Blacksburg 24061

\begin{abstract}
Sakthivel, K., Kumar, A., Devendrakumar, C., Vibhuti, M., Neelam, S., Gautam, R. K., Kumar, K., Dam Roy, S., and Vinatzer, B. A. 2016. Diversity of Ralstonia solanacearum strains on the Andaman Islands in India. Plant Dis. 100:732-738.

Fourteen Ralstonia solanacearum strains from solanaceous vegetables on the Andaman Islands, India, were characterized using a polyphasic approach. The strains wilted their respective hosts within 1 to 3 weeks postinoculation. Virulence assays on tomato (Solanum lycopersicum), brinjal (eggplant; S. melongena), and chili pepper (Capsicum annuиm) revealed that all strains were infective on all three hosts. However, tomato was more susceptible than eggplant and chili pepper. Strains were identified as $R$. solanacearum based on carbon substrate utilization profiling with

Biolog similarity coefficients $>0.82$. Species identity was further confirmed by $16 \mathrm{~S}$ ribosomal RNA and $r e c N$ gene sequence analysis. Intraspecific identification of strains revealed the presence of race 1 biovar 3 and race 1 biovar 4 . Both biovars wilted plants with similar aggressiveness. All strains were identified as phylotype I, and multilocus sequence typing revealed that the strains belong to a small number of clonal complexes that also comprise strains from mainland India, especially West Bengal state and Kerala.
\end{abstract}

The Andaman and Nicobar Islands in India comprise 572 islands in the Bay of Bengal, midway between peninsular India and Myanmar. Commercial or subsistence agricultural practices are relatively new to these islands, which were inhabited by indigenous tribes who depended on naturally available forest products for their livelihood (Mann 2005). Agricultural activities were promoted on the islands by the British Government in the 19th century and organized agriculture was practiced by the settlers only after 1940, with the establishment of state and central agricultural departments. These warm tropical islands have an environment that is highly conducive to many pests and diseases, with temperatures ranging from 18 to $34^{\circ} \mathrm{C}$, yearly rainfall of about $3,100 \mathrm{~mm}$, and relative humidity of 66 to $88 \%$. Vegetable cultivation is one of the most important agricultural activities on the islands because their remoteness necessitates growing vegetables to meet local demand. Solanaceous vegetables, mainly eggplant (brinjal; Solanum melongena), tomato (S. lycopersicum), and chili pepper (Capsicum annuиm), occupy one-fourth of the total vegetable cultivation area throughout the year. Bacterial wilt caused by Ralstonia solanacearum is a serious problem and causes 20 to $50 \%$ loss of solanaceous vegetable production on these islands every year (Singh et al. 2014).

$R$. solanacearum is a gram-negative, soilborne bacterium that belongs to the Proteobacteria subdivision (Yabuuchi et al. 1995) and has been described as a species complex due to its complex phenotypic and genotypic diversity (Palleroni and Doudoroff 1971). It has a wide host range, which includes more than 450 plant species in about 50 families, and is considered one of the most serious pathogens on diverse plant species in tropical, subtropical, and temperate regions (Guidot et al. 2014; Hayward 1991). The bacterium normally enters plant roots through wounds and spreads to xylem vessels, where it multiplies to high populations and produces copious amounts of exo-polysaccharides, which lead to clogging of vessels and, thereby, death of the host (Genin and Boucher 2002; Vasse

\section{Corresponding author: A. Kumar; E-mail: kumar@iari.res.in}

*The $\boldsymbol{e}$-Xtra logo stands for "electronic extra" and indicates that two supplementary figures and four supplementary tables are published online.

Accepted for publication 26 August 2015.

http://dx.doi.org/10.1094/PDIS-03-15-0258-RE

(C) 2016 The American Phytopathological Society et al. 1995). $R$. solanacearum species were classified into five races based on host range (Buddenhagen et al. 1962) and six biovars based on utilization of disaccharides and hexose alcohols (Hayward 1964).

With the onset of the genomic era, $R$. solanacearum was divided into four phylotypes (Fegan and Prior 2005; Poussier et al. 2000) corresponding to four broad genetic groups, each of them related to a geographic origin (phylotype I: Asia; phylotype II: America; phylotype III: Africa; and phylotype IV: Indonesia and Australia). Each phylotype can be further divided into sequence variants (sequevars) according to nucleotide polymorphisms of the endoglucanase precursor $(e g l)$ gene (Fegan and Prior 2005). In addition, based on multilocus sequence analysis (MLSA), Wicker et al. (2012) assigned $R$. solanacearum strains to a total of eight clades. Recently, Genin and Denny (2012) and Remenant et al. (2011) suggested reclassification of the $R$. solanacearum phylotypes into three separate species based on comparative genome analysis: $R$. sequeirae (corresponding to phylotypes I and III), $R$. solanacearum (corresponding to phylotype II), and $R$. haywardii (corresponding to phylotype IV and the previously described species $R$. celebensis and $R$. syzygii) (Taghavi et al. 1996).

The plant species belonging to the family Solanaceae are commonly infected by race 1 and race 3 of $R$. solanacearum, of which race 1 is prevalent in subtropical and tropical regions while race 3 is restricted to temperate regions (Kim-Lee et al. 2005). Bacterial wilt causes severe economic losses to vegetable production in the United States, Indonesia, Brazil, Colombia, Israel, South Africa, and many other vegetablegrowing countries (Floyd 2008). In India, the disease has been reported in Kerala, Karnataka, Himachal Pradesh, Sikkim, West Bengal, Assam, North Eastern State, and the Andaman Islands (Sagar et al. 2014) and was found to be caused by genetically highly diverse phylotype I strains that belong to biovar 3. Strains from the Andaman Islands were found to belong to three different sequevars (Ramesh et al. 2014).

The primary objective of the present study was to elucidate the genetic relationship of $R$. solanacearum strains obtained from eggplant, tomato, and chili grown in geographically diverse locations of the Andaman Islands with strains from other parts of the world, especially the Indian mainland, using a polyphasic approach, including MLSA and multilocus sequence typing (MLST).

\section{Materials and Methods}

Collection, isolation, characterization, and Biolog-based identification. Fourteen $R$. solanacearum (Smith) Yabuuchi strains from different solanaceous vegetables showing wilt symptoms from 
several geographical locations of the Andaman Islands were used in this study (Table 1). Isolation was performed as described by Kelman (1954). Briefly, stem pieces (2 to $3 \mathrm{~cm}$ long) excised from infected plants were washed five times in sterilized deionized water and blot dried for $15 \mathrm{~min}$ on an autoclaved paper towel. Stem pieces were placed in test tubes containing $5 \mathrm{ml}$ of sterile water for approximately 5 to $10 \mathrm{~min}$. Afterward, a loopful of each cell suspension was streaked onto Cassamino acid-peptone-glucose (CPG) agar (Cassamino acid, $1 \mathrm{~g} \mathrm{liter}^{-1}$; peptone, $10 \mathrm{~g} \mathrm{liter}^{-1}$; glucose, $10 \mathrm{~g} \mathrm{liter}^{-1}$; and agar, $15 \mathrm{~g} \mathrm{liter}^{-1}$; $\mathrm{pH}$ 7.2) amended with 2,3,5 triphenyl tetrazolium chloride ( $1 \%$ ) and incubated for 36 to $48 \mathrm{~h}$ at 28 to $30^{\circ} \mathrm{C}$. Fluidal white colonies with a pink center were subcultured, purified, and maintained in $15 \%$ glycerol at $-80^{\circ} \mathrm{C}$ for long-term storage. All strains were subjected to carbon substrate utilization profiling using the Microlog system (Biolog, Inc.). Bacterial cell suspensions prepared as per the manufacturer's instructions were pipetted into each of the 96 wells of the Biolog microplates and the plates were incubated at 28 to $30^{\circ} \mathrm{C}$ for 16 to $24 \mathrm{~h}$, then read with an automated plate reader (Biolog, Inc.).

Strain identification by $16 \mathrm{~S}$ ribosomal RNA and $\operatorname{recN}$ gene sequence analysis. For $16 \mathrm{~S}$ ribosomal (r)RNA amplification, 1,465-bp-long polymerase chain reaction (PCR) products were obtained using $50-\mu \mathrm{l}$ reaction mixtures, which consisted of $100 \mathrm{ng}$ of template DNA, $1 \times$ PCR buffer, $1.5 \mathrm{mM} \mathrm{MgCl}_{2}, 50 \mu \mathrm{M}$ each $\mathrm{dNTP}, 5 \mathrm{pmol}$ of each primer, and $1 \mathrm{U}$ of Taq DNA polymerase (Promega Corporation). PCR assays were performed in an Eppendorf themocycler (Model ProS Silver) with an initial denaturation of $96^{\circ} \mathrm{C}$ for $2 \mathrm{~min}$ followed by 35 cycles of $94^{\circ} \mathrm{C}$ for $30 \mathrm{~s}, 60^{\circ} \mathrm{C}$ for $1 \mathrm{~min}$, and $72^{\circ} \mathrm{C}$ for $1 \mathrm{~min}$. Reactions were completed with a final annealing step of $10 \mathrm{~min}$ at $72^{\circ} \mathrm{C}$. Similarly, for the recN gene, a 1,300-bp amplicon was generated using the following PCR conditions: initial denaturation at $96^{\circ} \mathrm{C}$ for $9 \mathrm{~min}$; followed by 30 cycles at $95^{\circ} \mathrm{C}$ for $1 \mathrm{~min}$, annealing at $60^{\circ} \mathrm{C}$ for $1 \mathrm{~min}$, and extension at $72^{\circ} \mathrm{C}$ for $90 \mathrm{~s}$; with a final extension of $72^{\circ} \mathrm{C}$ for $10 \mathrm{~min}$ (Kumar et al. 2013). All PCR products were resolved in a $1.0 \%$ agarose gel and purified using a Gel Elution kit according to the manufacturer's instructions (Sigma-Aldrich).

Cycle sequencing reactions were performed with 20 to $30 \mathrm{ng}$ of purified amplicon using the ABI PRISM BigDye Terminators v. 1.1 cycle sequencing kit according to the manufacturer's instructions (Applied Biosystems). Purified products were sequenced bidirectionally to obtain complete coverage. Sequences were edited and contigs were assembled in DNA baser and compared with GenBank sequences by BLAST analysis. Nucleotide sequence similarities were determined using the National Center for Biotechnology Information (NCBI) or European Molecular Biology Laboratory (EMBL) databases and the bacterial identity was established by closest match (Altschul et al. 1997)

Determination of biovar, race, and phylotype of $R$. solanacearum strains. Strains were assigned to biovars based on their ability to utilize or oxidize disaccharides (sucrose, lactose, and maltose) and sugar alcohols (mannitol, sorbitol, and dulicitol), as described by Hayward (1964). Briefly, $1.0 \mathrm{ml}$ of Hayward's medium was dispensed in microfuge tubes containing dextrose, lactose, maltose, cellobiose, dulicitol, mannitol, or sorbitol (1\% [wt/vol]), and $50 \mu \mathrm{l}$ of fresh bacterial cell suspensions of each strain $\left(1 \times 10^{8} \mathrm{CFU} / \mathrm{ml}\right.$ of sterile deionized water) was added. All the tubes were incubated at $28^{\circ} \mathrm{C}$ without agitation for 3 weeks. Two replications were conducted for each strain and observed for color change.

Race determination was performed using the leaf infiltration technique described by Lozano and Sequeira (1970). Five to six fully expanded leaves of 1-month-old Nicotiana tabacum plants were infiltrated in five to eight locations with bacterial suspensions (approximately $10^{8} \mathrm{CFU} / \mathrm{ml}$ ) using a disposable syringe without needle. Three replications were performed for each strain and plants were examined for symptoms at 24-h intervals for up to 2 weeks.

Strains were classified into phylotypes using the multiplex PCR method described by Fegan and Prior (2005). Genomic DNA was isolated from 24- to 48-h-old bacterial cultures by a modified cetyltrimethylammonium bromide method (Kumar et al. 2004). The DNA was resuspended $(200 \mathrm{ng} / \mu \mathrm{l})$ in sterile MilliQ water and used as template in PCR assays. PCR assays with the primers described by Fegan and Prior (2005) were performed using the GoTaq PCR kit according to the manufacturer's instructions (Promega Corporation), with initial denaturation of $96^{\circ} \mathrm{C}$ for $5 \mathrm{~min}$; followed by 35 cycles of denaturation $94^{\circ} \mathrm{C}$ for $15 \mathrm{~s}$, annealing at $59^{\circ} \mathrm{C}$ for $30 \mathrm{~s}$, and extension at $72^{\circ} \mathrm{C}$ for $30 \mathrm{~s}$; and a final extension at $72^{\circ} \mathrm{C}$ for $10 \mathrm{~min}$. The reaction mixture $(50 \mu \mathrm{l})$ contained $100 \mathrm{ng}$ of template DNA, $1 \times$ PCR buffer, $1.5 \mathrm{mM} \mathrm{MgCl}_{2}, 50 \mu \mathrm{M}$ each dNTP, 6 to $18 \mathrm{pmol}$ of primers, and $2 \mathrm{U}$ of Taq DNA polymerase. PCR products were resolved in a $1.5 \%$ agarose gel and visualized by ethidium bromide staining. Phylotypes were assigned to strains based on amplicon size.

Pathogenicity of $\boldsymbol{R}$. solanacearum strains. Pathogenicity of all strains was first determined on tomato plants. Assays were performed using the soil inoculation method described previously (Kumar 2006). Bacterial suspensions $(20 \mathrm{ml})$ at a concentration of $1 \times 10^{8}$ $\mathrm{CFU} / \mathrm{ml}$ (absorbance at $600 \mathrm{~nm}=0.5$ to 1.0 ) were poured around the root zone of 3-week-old 'Pusa Ruby' tomato seedlings and incubated at 28 to $32^{\circ} \mathrm{C}, 80 \%$ relative humidity, and 30,000 lux illuminance in a glasshouse for up to 6 weeks for wilt development. Three plants were inoculated for each strain. The experiment was repeated two times. Control plants were treated with sterile water in a similar manner. Three replications were performed for each strain and wilt incidence was calculated.

The fourteen $R$. solanacearum strains were inoculated on tomato (Solanum lycopersicum, cultivar 'Pusa Ruby'), eggplant (cultivar 'Pusa Purple Long') and chili pepper (cultivar 'Co-1') as described above. Wilt incidence was recorded at weekly intervals and wilting percentage was calculated using the following formula at the end of the experiment. All the percentage data were analyzed statistically after arcsine transformation and the mean comparisons were carried

Table 1. Characterization of Ralstonia solanacearum strains collected from the Andaman Islands

\begin{tabular}{lllllc}
\hline Strains & Host & Year & \multicolumn{1}{c}{ Origin } & Biovar, race, phylotype & Biolog similarity coefficient \\
\hline TRs-Hv & Tomato & 2013 & Havelock Islands & Biovar 4, race 1, phylotype I & 0.85 \\
TRs-Dg & Tomato & 2013 & Diglipur & Biovar 3, race 1, phylotype I & 0.86 \\
CRs-Gr2 & Chili & 2013 & Garacharma & Biovar 4, race 1, phylotype I & 0.82 \\
CRs-Sg & Chili & 2013 & Guptapara & Biovar 3, race 1, phylotype I & 0.84 \\
CRs-Gr1 & Chili & 2013 & Garacharma & Biovar 3, race 1, phylotype I & 0.83 \\
CRs-Wn & Chili & 2013 & Wandoor & Biovar 3, race 1, phylotype I & 0.87 \\
CRs-Cl & Chili & 2013 & Calicut & Biovar 3, race 1, phylotype I & 0.83 \\
CRs-Gr & Chili & 2013 & Garacharma & Biovar 3, race 1, phylotype I & 0.86 \\
CRs-Ch & Chili & 2013 & Chidiyatapu & Biovar 3, race 1, phylotype I & 0.82 \\
BRs-Hv1 & Eggplant & 2013 & Havelock & Biovar 3, race 1, phylotype I & 0.84 \\
BRs-Gr & Eggplant & 2013 & Garacharma & Biovar 3, race 1, phylotype I & 0.89 \\
BRs-Dg1 & Eggplant & 2013 & Diglipur & Biovar 3, race 1, phylotype I & 0.85 \\
BRs-Dg2 & Eggplant & 2013 & Diglipur & Biovar 3, race 1, phylotype I & 0.88 \\
BRs-Hb & Eggplant & 2013 & Humphreygunj & Biovar 3, race 1, phylotype I & 0.83 \\
\hline
\end{tabular}


out by Duncan's Multiple Range Test $(P<0.05)$ (Gomez and Gomez 1984).

$$
\text { Wilting percentage }=\frac{\text { Number of plant wilted } \times 100}{\text { Total number of plants inoculated }}
$$

Genotyping by MLST. MLST-based genotyping was conducted on each strain as described by Castillo and Greenberg (2007). This MLST scheme exploits variation in nucleotide sequences of five chromosomal housekeeping genes (phosphoenolpyruvate synthase; DNA gyrase, subunit B; adenylate kinase; glutamate dehydrogenase oxidoreductase; and glyceraldehyde 3-phosphate dehydrogenase oxidoreductase) and three megaplasmid-borne virulence-related genes (regulatory transcription regulator, encoding flagellin protein, and egl) (Supplementary Table S3). PCR was carried out as described previously (Kumar et al. 2014). Briefly, the reaction mixture $(50 \mu \mathrm{l})$ contained $100 \mathrm{ng}$ of template DNA, $1 \times$ PCR buffer, $1.5 \mathrm{mM} \mathrm{MgCl} 2,50 \mu \mathrm{M}$ each dNTP, $6 \%$ dimethyl sulfoxide, 10 pmol of primers, and $1 \mathrm{U}$ of Taq DNA polymerase. The PCR thermal profile included a 9 -min denaturation step at $96^{\circ} \mathrm{C}$; followed by 30 cycles at $95^{\circ} \mathrm{C}$ for $1 \mathrm{~min}$, the appropriate annealing temperature for $1 \mathrm{~min}$, and extension temperature of $72^{\circ} \mathrm{C}$ for $2 \mathrm{~min}$; with a final extension step at $72^{\circ} \mathrm{C}$ for $10 \mathrm{~min}$.

All sequences were end trimmed, edited, annotated, and submitted to GenBank (Supplementary Table S4). For MLST, strain information and sequences were added to the Plant Associated and Environmental Microbes Database (PAMDB; http://genome.ppws.vt.edu/ cgi-bin/MLST/home.pl) (Almeida et al. 2010). Sequences for all eight loci were concatenated, and used for establishing phylogeny. All sequences were deposited in public databases such as NCBI, EMBL, and DNA Data Bank of Japan (Supplementary Table S1). A phylogenetic tree was constructed with the concatenated sequences totaling 5379 bp using the Neighbor-Joining method (Saitou and Nei 1987). Evolutionary distances were computed using the Maximum Composite Likelihood method (Tamura et al. 2004). Evolutionary analyses were conducted in MEGA 6.04 (Tamura et al. 2013). The nodal robustness was tested by bootstrap method (Felsenstein 1985)
Allelic profiles (sequence types [ST]) were assigned to strains based on the allele profiles in PAMDB (Almeida et al. 2010). The eBURST program (http://eburst.mlst.net), an algorithm exclusively developed for analyzing microbial MLST data, was used to analyze the allelic data (Feil et al. 2004; Spratt et al. 2004). The following settings for the creation of the eBURST-based population snapshot were used: number of loci per strain $=8$, minimum number of identical loci for group definition $=1$, minimal single-locus variant count for subgroup definition $=1$, and number of resamplings for bootstrap analysis $=1,000$.

\section{Results}

Collection, isolation, characterization, and Biolog-based identification of $\boldsymbol{R}$. solanacearum strains. Fourteen bacterial strains from tomato, eggplant, and chili pepper expressing

Table 2. Host susceptibility of 14 Ralstonia solanacearum strains on three hosts

\begin{tabular}{|c|c|c|c|c|c|c|}
\hline \multirow[b]{2}{*}{ Strain } & \multicolumn{6}{|c|}{ Pathogenicity and virulence $^{\mathrm{z}}$} \\
\hline & Tomato & DW & Chili & DW & Eggplant & DW \\
\hline TRs_Hv & 77.7 (61.8 a) & 7 & $33.3(35.2 \mathrm{a})$ & 15 & $33.3(35.2 \mathrm{a})$ & 21 \\
\hline TRs_Dg & $6.6(54.7 \mathrm{a})$ & 3 & $22.2(28.1 \mathrm{a})$ & 13 & 35.2 a) & 28 \\
\hline CRs_Sg & $22.2(28.1 \mathrm{a})$ & 11 & $44.4(41.8 \mathrm{a})$ & 13 & $22.2(28.1 \mathrm{a})$ & 11 \\
\hline CRs_Gr1 & 44.4 (41.8 a) & 7 & $55.5(48.2 \mathrm{a})$ & 11 & 28.1 a) & 20 \\
\hline CRs_Gr2 & $66.6(54.7 \mathrm{a})$ & 9 & $33.3(35.2$ a) & 16 & & 16 \\
\hline CRs_Wn & $44.4(41.8 \mathrm{a})$ & 5 & $33.3(35.2 \mathrm{a})$ & 10 & 11.1 & 24 \\
\hline CRs_Cl & $33.3(35.2 \mathrm{a})$ & 7 & $66.6(54.7 \mathrm{a})$ & 24 & 22.2 & 18 \\
\hline CRs_Gr & $33.3(35.2 \mathrm{a})$ & 15 & $66.6(54.7 \mathrm{a})$ & 26 & 33.3 & 18 \\
\hline CRs_Ch & $44.4(41.8 \mathrm{a})$ & 7 & $33.3(35.2 \mathrm{a})$ & 23 & 44.4 & 17 \\
\hline BRs_Hv1 & $55.5(48.2 \mathrm{a})$ & 5 & $44.4(41.8)$ & 22 & $88.9(70.5 \mathrm{a})$ & 10 \\
\hline BRs_Gr & $55.5(48.2 \mathrm{a})$ & 7 & $55.5(48.2 \mathrm{a})$ & 19 & $44.4(41.8 \mathrm{a})$ & 21 \\
\hline BRs_Dg1 & $66.6(54.7 \mathrm{a})$ & 7 & $22.2(28.1 \mathrm{a})$ & 21 & $66.6(54.7 \mathrm{a})$ & 11 \\
\hline BRs_Dg2 & $44.4(41.8 \mathrm{a})$ & 7 & $11.1(19.5 \mathrm{a})$ & 24 & $55.5(48.2 \mathrm{a})$ & 20 \\
\hline BRs_Hb & $44.4(41.8 \mathrm{a})$ & 5 & $11.1(19.5 \mathrm{a})$ & 18 & $44.4(41.8 \mathrm{a})$ & 16 \\
\hline
\end{tabular}

${ }^{\mathrm{z}}$ Mean of three replications. DW = days to wilt. Figures in the parentheses are arcsine transformed values. In a column, means followed by common letters are not significantly different $(P=0.05)$ in Duncan's multiple range test.

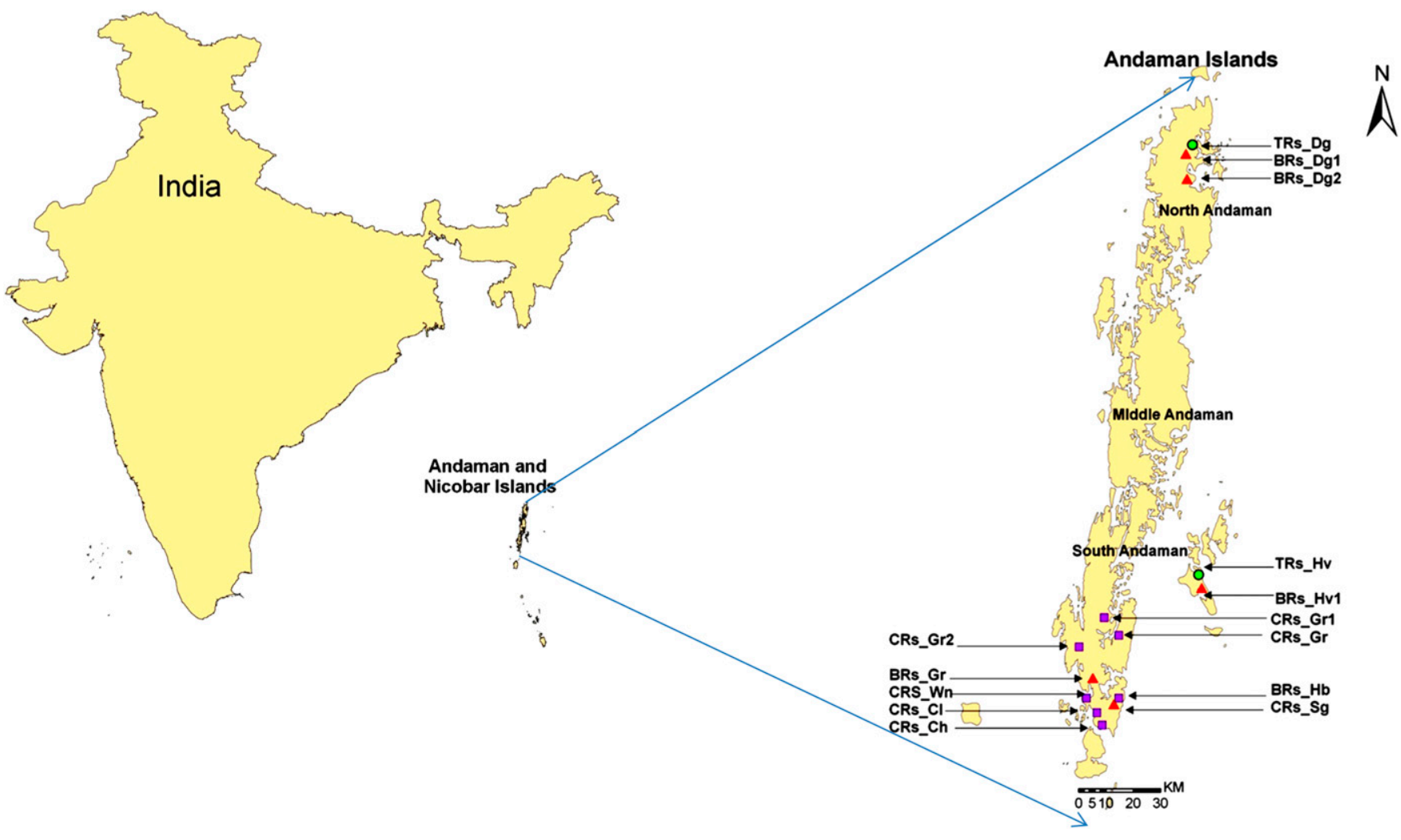

Fig. 1. Geographic location of the Andaman and Nicobar Islands and collection sites of 14 Ralstonia solanacearum strains. 
wilting symptoms were collected on the Andaman Islands (Table 1; Fig. 1). Our polyphasic approach identified the strains as $R$. solanacearum. Morphologically, the colonies were highly fluidal, with pink spiral centers on CPG medium amended with 2,3,5-tetrazolium chloride. Biolog, based on utilization of 71 carbon sources and 23 chemical sensitivity assays, confirmed

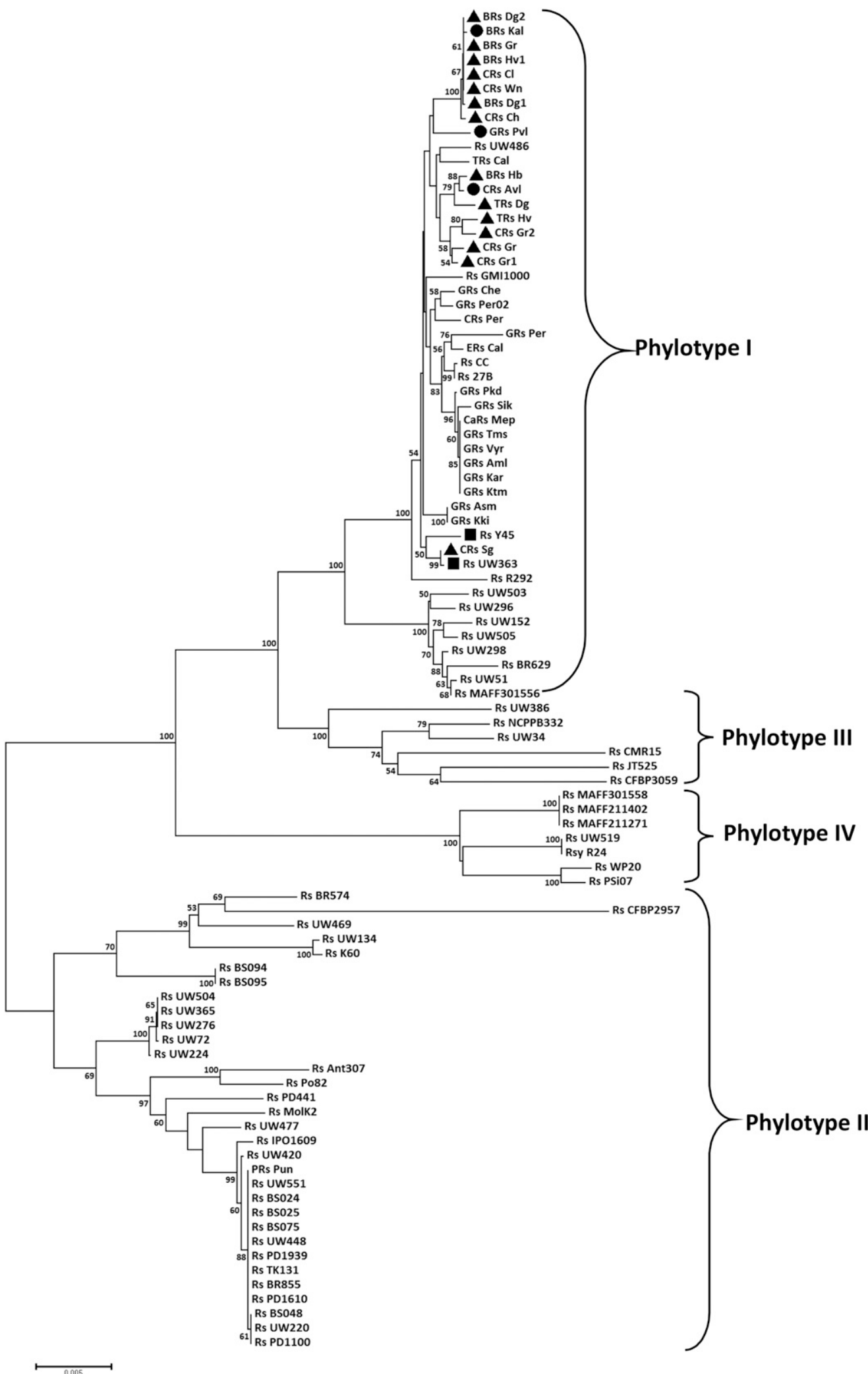

Fig. 2. Phylogenetic relationships among Ralstonia solanacearum strains from the Andaman Islands, mainland India, and other strains from around the world were inferred using the neighborjoining method (Saitou and Nei 1987). The percentage of replicate trees in which the associated taxa clustered together in the bootstrap test $(1,000$ replicates) is shown next to the branches (Felsenstein 1985). The tree is drawn to scale, with branch lengths in the same units as those of the evolutionary distances used to infer the phylogenetic tree. The analysis involved $93 R$. solanacearum strains ( 14 strains from this study and 79 strains found in the multilocus sequence typing database PAMDB (71 strains) and GenBank ( 8 strains). All positions containing gaps and missing data were eliminated. Symbols: $\boldsymbol{\Delta}=$ Andaman Island strains, $\boldsymbol{O}=$ Indian mainland strains, and $\mathbf{\square}=$ Chinese strains UW363 and Y45. 
the identity of the strains as $R$. solanacearum $(>0.82$ similarity coefficient).

Strain identification by $16 \mathrm{~S}$ rRNA and $r e c N$ gene sequence analysis. BLAST analysis of the $16 \mathrm{~S}$ rRNA and the $r e c N$ gene sequences further confirmed the identity of the strains as $R$. solanacearum because DNA identity was greater than $99 \%$ compared with $R$. solanacearum entries in GenBank. The $16 \mathrm{~S}$ rRNA and recN gene sequences of the strains were assigned GenBank Accessions numbers (16S rRNA gene: KJ010171 to KJ010184; recN gene: KJ628295 to KJ628308).

Determination of biovar, race, and phylotype of $R$. solanacearum strains. Biovar tests indicated that, among the 14 strains, 12 belong to biovar 3 and 2 (TRs-Hv isolated from tomato and CRs-Gr2 isolated from chili pepper) belong to biovar 4 (Table 1). All strains induced dark-brown necrotic lesions surrounded by a clear yellow halo, which appeared 2 days postinoculation (dpi) at the point of infiltration on tobacco leaf tissue. This was followed by systemic infection resulting in wilting of whole plants in 5 to 6 days. This indicated that all strains belong to race 1. Multiplex PCR-based phylotyping of all strains yielded two specific amplicons (289 and $150 \mathrm{bp}$ ), indicating that all strains belong to phylotype I.

Pathogenicity and virulence assays. All strains induced wilt symptoms in 21-day-old tomato plants within 3 to 7 dpi. Pathogenicity assays on tomato, eggplant, and chili pepper indicated that all strains infected all hosts, with minor variation in incubation time. The tested strains induced wilt symptoms on tomato relatively earlier (7.2 dpi) and with a higher average wilting percentage (46.3\%) compared with the other two hosts. In eggplant, the average wilting percentage was $29.7 \%$ and the number of days to express the first wilt symptom was $17.7 \mathrm{dpi}$. In chili pepper, the average wilting percentage and incubation time for the first wilt symptoms to appear were 28.6 and 18.2 , respectively. The tomato strain TRs-Dg was the most aggressive strain: it caused wilting in 3 days. Strain TRs-Dg was followed by the chili pepper strain, CRs-Wn, and the eggplant strain, BRs-Hb, which caused wilting by 5 dpi. Tomato was more susceptible than chili pepper and eggplant (Table 2)

MLST of R. solanacearum strains. The sequences from all eight loci were concatenated (5,379 bp) and subjected to multiple alignment. A phylogenetic tree was constructed using the neighborjoining-method (Fig. 2). Very similar trees were obtained using the unweighted pair-group method with arithmetic mean method and the maximum-likelihood method. All three trees clearly revealed a single clade of phylotype I strains. Several mainland India strains isolated from solanaceous and zingiberaceous vegetables were found to cluster with all but one of the strains from the Andaman Islands within the phylotype I clade (Fig. 2). Because bootstrapping revealed low statistical support for branching with the phylotype I clade, not much else can be deduced from the phylogenetic analysis. The one Andaman Islands strain that did not cluster with the other strains was the chili pepper strain CRs-Sg, which clustered with solanaceous strains UW363 and Y45 from China.

We further assigned allele numbers to each allele at each locus to obtain ST. eBurst analysis revealed 10 ST (Table 3), whereby ST1 is composed of five strains and all other ST are represented by only one strain each. Three ST (ST1, -2, and -3) were part of the same clonal complex because ST2 and ST3 are each single-locus variants (SLV) of ST1 (Table 3; Supplementary Table S2). ST4 and ST5 are double-locus variants (DLV) of each other and form a second clonal complex, and ST6 and ST7 are DLV of each other and form a third clonal complex. Interestingly, ST1 (allele profile: 24, $10,29,10,10,8,42,28)$ is also an SLV of a strain collected from the Mohanpur region of West Bengal (BRs-Kal-ST917; allele profile: $24,10,29,10,10,8,30,28$; Kumar et al. 2014) on the Indian mainland.

\section{Discussion}

Bacterial wilt of solanaceous vegetables incited by race 1 of $R$. solanacearum causes severe economic losses in many countries of the world (Hayward 1991). On the Andaman Islands, bacterial wilt is one of the major causes of low productivity of vegetables (Singh et al. 2014). In the present work, 14 strains collected from diseased tomato, eggplant, and chili pepper from the main vegetablegrowing areas of the Andaman Islands were analyzed. All strains were identified through a series of morphological, biochemical, and molecular approaches.

Phylotype classification revealed that the collected strains belong to phylotype I, for which an Asian origin has been proposed (Genin and Denny 2012), and which are commonly found on the Indian mainland (Kumar et al. 2014). We did not identify any phylotype IV strains, for which a Southeast Asian origin has been proposed (Genin and Denny 2012), although the Andaman Islands are located closer to Southeast Asian countries than the Indian subcontinent. Although this result is in agreement with an introduction of $R$. solanacearum to the Andaman Islands from the Indian mainland, this cannot be definitely concluded because all phylotypes are found on all continents today. All strains belong to race 1 because they induced dark-brown necrotic lesions on tobacco leaves at the site of

Table 3. Multilocus sequence typing allelic profiles of Ralstonia solanacearum strains collected from solanaceous hosts from the Andaman Islands ${ }^{\mathrm{z}}$

\begin{tabular}{|c|c|c|c|c|c|c|c|c|c|c|c|}
\hline Strain & ST & $\begin{array}{l}\text { Race, } \\
\text { biovar }\end{array}$ & ID & ppsA & fliC & hrpB & gapA & $\operatorname{gdh} A$ & $a d k$ & $\operatorname{gyr} B$ & egl \\
\hline CRs-Wn & ST1 (SLV of ST2) & $\mathrm{r} 1, \mathrm{~b} 3$ & 1333 & 24 & 10 & 29 & 10 & 10 & 8 & 42 & 28 \\
\hline CRs-Cl & ST1 (SLV of ST2) & $\mathrm{r} 1, \mathrm{~b} 3$ & 1334 & 24 & 10 & 29 & 10 & 10 & 8 & 42 & 28 \\
\hline BRs-Hv1 & ST1 (SLV of ST2) & $\mathrm{r} 1, \mathrm{~b} 3$ & 1337 & 24 & 10 & 29 & 10 & 10 & 8 & 42 & 28 \\
\hline BRs-Gr & ST1 (SLV of ST2) & $\mathrm{r} 1, \mathrm{~b} 3$ & 1338 & 24 & 10 & 29 & 10 & 10 & 8 & 42 & 28 \\
\hline BRs-Dg2 & ST1 (SLV of ST2) & $\mathrm{r} 1, \mathrm{~b} 3$ & 1340 & 24 & 10 & 29 & 10 & 10 & 8 & 42 & 28 \\
\hline $\mathrm{CRs}-\mathrm{Ch}$ & ST2 (SLV of ST1) & $\mathrm{r} 1, \mathrm{~b} 3$ & 1336 & 24 & 10 & 29 & 9 & 10 & 8 & 42 & 28 \\
\hline BRs-Dg1 & $\begin{array}{c}\text { ST3 (SLV of ST } 2 \\
\text { or DLV of ST1) }\end{array}$ & $\mathrm{r} 1, \mathrm{~b} 3$ & 1339 & 24 & 10 & 29 & 10 & 10 & 8 & 42 & 27 \\
\hline CRs-Gr1 & ST4 & $\mathrm{r} 1, \mathrm{~b} 3$ & 1331 & 1 & 10 & 11 & 9 & 26 & 8 & 37 & 27 \\
\hline CRs-Gr & ST5 (DLV of ST4) & & 1335 & 1 & 10 & 32 & 9 & 26 & 8 & 39 & 27 \\
\hline TRs-Hv & ST6 (DLV of ST7) & $\mathrm{r} 1, \mathrm{~b} 4$ & 1328 & 28 & 23 & 30 & 9 & 26 & 8 & 36 & 27 \\
\hline CRs-Gr2 & ST7 (DLV of ST6) & $\mathrm{r} 1, \mathrm{~b} 4$ & 1332 & 28 & 20 & 30 & 9 & 26 & 8 & 38 & 27 \\
\hline BRs-Hb & ST8 & $\mathrm{r} 1, \mathrm{~b} 3$ & 1341 & 24 & 10 & 30 & 30 & 26 & 1 & 41 & 27 \\
\hline CRs-Sg & ST9 & $\mathrm{r} 1, \mathrm{~b} 3$ & 1330 & 10 & 10 & 11 & 10 & 11 & 7 & 40 & 11 \\
\hline TRs-Dg & ST10 & $\mathrm{r} 1, \mathrm{~b} 3$ & 1329 & 28 & 23 & 10 & 9 & 26 & 1 & 41 & 27 \\
\hline
\end{tabular}

z ST = sequence type; ID = Plant Associated and Environmental Microbes Database identification number; $p p s A=$ phosphoenolpyruvate synthase; $g y r B=$ DNA gyrase = subunit B; $a d k=$ adenylate kinase; $g d h A=$ glutamate dehydrogenase oxidoreductase; and gap $A=$ glyceraldehyde 3-phosphate dehydrogenase oxidoreductase; $h r p B=$ regulatory transcription regulator; $f l i C=$ encoding flagellin protein; $e g l=$ endoglucanase precursor; SLV = single-locus variants; DLV = double-locus variants; $\mathrm{r} 1, \mathrm{~b} 3=$ race 1 , biovar 3; and r1, b4 = race 1, biovar 4 . ST1, ST2, and ST3 = clonal complex comprising five biovar 3 strains that share all alleles; ST4 and ST5 = clonal complex consisting of two strains that are DLV; ST6 = triple-locus variant of ST10, the biovar 4 isolate; ST7 = DLV of ST6; and ST8 and ST9 = singletons. 
inoculation at $2 \mathrm{dpi}$, which was followed by systemic wilting of whole plants. Biovar tests revealed the presence of biovar 3 (12 strains) and biovar 4 (2 strains). Both biovars are known to affect solanaceous crops (Hayward 1991). Race 4 strains infecting Zingiberaceae family members in India where also found to mostly belong to biovar 3, with a minority of strains belonging to biovar 4 (Kumar et al. 2014). A recent study of phylotype I strains from the Solanaceae family in India, including the Andaman Islands, identified only biovar 3 strains (Ramesh et al. 2014). Therefore, biovar 3 strains appear to be more common than biovar 4 strains in India, including the Andaman Islands, but sampling of additional strains will be necessary to confirm these results.

Strains belonging to biovar 3 or 4 caused nearly identical disease development patterns on plants, and no intrabiovar variation in regard to virulence on tomato, eggplant, or chili pepper was observed. Among the three analyzed host plants, tomato was the most susceptible, which is similar to results reported by Ramesh et al. (2014), who found that tomato and eggplant hosts were more susceptible to most strains compared with chili pepper.

MLST revealed that five of the biovar 3 strains isolated from eggplant and chili pepper were identical at eight MLST loci. We refer to these as ST1. ST1 strains only differed at one locus from a strain that we assigned ST2 and they only differed at one other locus from a strain assigned ST3. Thus, ST1, ST2, and ST3 strains form a single clonal complex. The other strains share fewer alleles but, because all strains equally infected eggplant, tomato, and chili pepper, no changes in host range occurred during genetic diversification. Interestingly, even the two biovar 4 strains share alleles at five loci with one of the biovar 3 strains, TRs-Dg. Collectively, the data indicate intrabiovar and intrarace genetic variability with no consequences for pathogenicity or virulence on solanaceous hosts.

Because 5 of the 14 analyzed strains belong to a single ST (ST1) and these strains were isolated from diverse geographical locations and different host plants on the islands, $R$. solanacearum strains appear to be frequently exchanged between island locations. Dissemination most likely occurs with planting material or transplants. Tomato fruit harvested from partially wilted tomato plants have been reported to harbor $R$. solanacearum (Sanchez Perez et al. 2008; Shakya 1993). Additionally, natural seed infection in tomato and eggplant has been suggested for race 1 of $R$. solanacearum (Chatterjee et al.1994; Sanchez Perez et al. 2008; Shekhawat et al. 1992). Finally, contamination of tomato and capsicum seed has been reported to yield wilted plantlets in the field at low frequency (Devi and Menon 1980; Moffett et al. 1981). This appears similar to the transstate spread of race 4 and race 3 strains of $R$. solanacearum in mainland India, which was attributed to movement of latently infected or contaminated ginger rhizomes and potato tubers (Janse 1996; Kumar 2006; Kumar and Abraham 2008; Kumar et al. 2004).

An interesting observation is also that the five ST1 strains on the Andaman Islands are SLV of a strain that is prevalent in eggplant fields in the Mohanpur regions of West Bengal (BRs-Kal) in mainland India (Kumar et al. 2013). Additionally, most Andaman Islands strains cluster with mainland India strains based on phylogenetic analysis. This suggests that the phylotype I population of $R$. solanacearum was introduced to the Andaman Islands from mainland India. An interesting question is how frequent such introductions have been. To answer this question, an informative comparison can be made with a study of the genetic diversity of $R$. solanacearum race 3 biovar 2 strains in Europe (Clarke et al. 2015). This study found that, even at the whole-genome level, only a very small number of mutations occurred in over 50 years since the pathogen was imported from South America into Europe. Therefore, the presence of 10 different ST among only 14 analyzed strains from the Andaman Islands suggests that strains belonging to these 10 different ST were imported separately from mainland India. In fact, these $10 \mathrm{ST}$ are differentiated from each other by mutations in less than $6,000 \mathrm{bp}$ of sequenced genome, which indicates that thousands of mutations distinguish these strains from each other at the whole-genome level. This makes it highly unlikely that this diversity evolved on the Andaman Islands after Indian settlers arrived on the islands starting from the later period of the 19th century (Mann 2005). Therefore, $R$. solanacearum strains have probably been introduced to the Andaman Islands numerous times from the mainland over the last 100 years, contributing to the high bacterial wilt incidence on the islands today.

\section{Acknowledgments}

We thank the Directors of Indian Council of Agricultural Research-Central Island Agricultural Research Institute, Port Blair and Indian Council of Agricultural Research-Indian Agricultural Research Institute, New Delhi for their support of the project.

\section{Literature Cited}

Almeida, N. F., Yan, S., Cai, R., Clarke, C. R., Morris, C. E., Schaad, N. W. Schuenzel, E. L., Lacy, G. H., Sun, X., Jones, J. B., Castillo, J. A., Bull, C. T., Leman, S., Guttman, D. S., Setubal, J. C., and Vinatzer, B. A. 2010. PAMDB, a multilocus sequence typing and analysis database and website for plant-associated microbes. Phytopathology 100:208-215.

Altschul, S. F., Madden, T. L., Schaeffer, A. A., Zhang, J., Zhang, Z., Miller, W., and Lipman, D. J. 1997. Gapped BLAST and PSI-BLAST: A new generation of protein database search programs. Nucleic Acids Res. 25:3389-3402.

Buddenhagen, I. W., Sequeira, L., and Kelman, A. 1962. Designation of races of Pseudomonas solanacearum. (Abstr.) Phytopathology 52:726.

Castillo, J. A., and Greenberg, J. T. 2007. Evolutionary dynamics of Ralstonia solanacearum. Appl. Environ. Microbiol. 73:1225-1238.

Chatterjee, B., Chakraborty, M., Habib, A. K. M. A., and Samaddar, K. R. 1994 Survival of Pseudomonas solanacearum biovar 3 on seeds of eggplant. Bact. Wilt Newsl. 11:11.

Clarke, C. R., Studholme, D. J., Weisberg, A., Hayes, B., Runde, B., Cai, R., Wroblewski, T., Daunay, M. C., Castillo, J., Wicker, E., and Vinatzer, B. A 2015. Genome-enabled phylogeographic investigation of the quarantine pathogen Ralstonia solanacearum race 3 biovar 2 and screening for sources of resistance against its core effectors. Phytopathology 105:597-607.

Devi, L. R., and Menon, M. R. 1980. Transmission of Pseudomonas solanacearum through tomato seeds. Agric. Res. J. Kerala. 18:120-122.

Fegan, M., and Prior, P. 2005. How complex is the "Ralstonia solanacearum species complex"? Pages 449-461 in: Bacterial Wilt Disease and the Ralstonia solanacearum Species Complex. C. Allen, P. Prior, and A. C. Hayward, eds. American Phytopathological Society, St. Paul, MN.

Feil, E. J., Li, B. C., Aanensen, D. M., Hanage, W. P., and Spratt, B. G. 2004. EBURST: Inferring patterns of evolutionary descent among clusters of related bacterial genotypes from multilocus sequence typing data. J. Bacteriol. 186: 1518-1530.

Felsenstein, J. 1985. Confidence limits on phylogenies: An approach using the bootstrap. Evolution 39:783-791.

Floyd, J. 2008. New Pest Response Guidelines: Ralstonia solanacearum Race 3 Biovar 2. USDA-APHIS-PPQ-Emergency and Domestic Programs, Riverdale, MD.

Genin, S., and Boucher, C. 2002. Ralstonia solanacearum: Secrets of a major pathogen unveiled by analysis of its genome. Mol. Plant Pathol. 3:111-118.

Genin, S., and Denny, T. P. 2012. Pathogenomics of the Ralstonia solanacearum species complex. Annu. Rev. Phytopathol. 50:67-89.

Gomez, K. A., and Gomez, A. A. 1984. Statistical Procedures for Agricultural Research, 2nd ed. John Wiley and Sons, Inc., London.

Guidot, A., Jiang, W., Ferdy, J. B., Thébaud, C., Barberis, P., Gouzy, J., and Genin, S. 2014. Multihost experimental evolution of the pathogen Ralstonia solanacearum unveils genes involved in adaptation to plants. Mol. Biol. Evol. 31:2913-2928.

Hayward, A. C. 1964. Characteristics of Pseudomonas solanacearum. J. Appl. Bacteriol. 27:265-277.

Hayward, A. C. 1991. Biology and epidemiology of bacterial wilt caused by Pseudomonas solanacearum. Annu. Rev. Phytopathol. 29:65-87.

Janse, J. D. 1996. Potato brown rot in Western Europe-History, present occurrence and some remarks on possible origin, epidemiology and control strategies. Bull. OEPP/EPPO Bull. 26:679-695

Kelman, A. 1954. The relationship of pathogenicity in Pseudomonas solanacearum to colony appearance on a tetrazolium chloride medium. Phytopathology 44:693-695.

Kim-Lee, H., Moon, J. S., Hong, Y. J., Kim, M. S., and Cho, H. M. 2005. Bacterial wilt resistance in the progenies of the fusion hybrids between haploid of potato and Solanum commersonii. Am. J. Potato Res. 82:129-137.

Kumar, A. 2006. Methods for screening ginger (Zingiber officinale Rosc.) for bacterial wilt resistance. Ind. Phytopathol. 59:281-286.

Kumar, A., and Abraham, S. 2008. PCR based detection of bacterial wilt pathogen, Ralstonia solanacearum in ginger rhizomes and soil collected from bacterial wilt affected field. J. Spices Aromat. Crops 17:109-113.

Kumar, A., Prameela, T. P., and Suseelabhai, R. 2013. A unique DNA repair and recombination gene $(\mathrm{recN})$ sequence for identification and intraspecific molecular typing of bacterial wilt pathogen Ralstonia solanacearum and its comparative analysis with ribosomal DNA sequences. J. Biosci. 38:267-278.

Kumar, A., Prameela, T. P., Suseelabhai, R., Siljo, A., Anandaraj, M., and Vinatzer, B. A. 2014. Host specificity and genetic diversity of race 4 strains of Ralstonia solanacearum. Plant Pathol. 63:1138-1148. 
Kumar, A., Sarma, Y. R., and Anandaraj, M. 2004. Evaluation of genetic diversity of Ralstonia solanacearum causing bacterial wilt of ginger using REP-PCR and PCR-RFLP. Curr. Sci. 87:1555-1561.

Lozano, J. C., and Sequeira, L. 1970. Differentiation of races of Pseudomonas solanacearum by a leaf infiltration. Phytopathology 60:833-838.

Mann, R. S. 2005. Andaman and Nicobar Tribes Restudied: Encounters and Concerns. Mittal Publications, New Delhi, India.

Moffett, M. L., Wood, B. A., and Hayward, A. C. 1981. Seed and soil: Sources of inoculum for the colonisation of the foliage of solanaceous hosts by Pseudomonas solanacearum. Ann. Appl. Biol. 98:403-411.

Palleroni, N. J., and Doudoroff, M. 1971. Phenotypic characterization and deoxyribonucleic acid homologies of Pseudomonas solanacearum. J. Bacteriol. 107:690-696.

Poussier, S., Trigalet-Demery, D., Vandewalle, P., Goffinet, B., Luisetti, J., and Trigalet, A. 2000. Genetic diversity of Ralstonia solanacearum as assessed by PCR-RFLP of the hrp gene region, AFLP and 16S rRNA sequence analysis and identification of an African subdivision. Microbiology 146:1679-1692.

Ramesh, R., Gauri, A. A., and Gaitonde, S. 2014. Genetic diversity of Ralstonia solanacearum infecting solanaceous vegetables from India reveals the existence of unknown or newer sequevars of phylotype I strains. Eur. J. Plant Pathol. 140:543-562

Remenant, B., de Cambiaire, J. C., Cellier, G., Jacobs, J. M., Mangenot, S., Barbe, V., Lajus, A., Vallenet, D., Medigue, C., Fegan, M., Allen, C., and Prior, P. 2011. Ralstonia syzygii, the blood disease bacterium and some Asian $R$. solanacearum strains form a single genomic species despite divergent lifestyles. PLoS One 6:e24356.

Sagar, V., Jeevalatha, A., Mian, S., Chakrabarti, S. K., Gurjar, M. S., Arora, R. K., Sharma, S., Bakade, R. R., and Singh, B. P. 2014. Potato bacterial wilt in India caused by strains of phylotype I, II and IV of Ralstonia solanacearum. Eur. J. Plant Pathol. 138:51-65.

Saitou, N., and Nei, M. 1987. The neighbor-joining method: A new method for reconstructing phylogenetic trees. Mol. Biol. Evol. 4:406-425.

Sanchez Perez, A., Mejia, L., Fegan, M., and Allen, C. 2008. Diversity and distribution of Ralstonia solanacearum strains in Guatemala and rare occurrence of tomato fruit infection. Plant Pathol. 57:320-331.
Shakya, D. D. 1993. Seed transmission of Pseudomonas solanacearum in tomato. Pages 371-372 in: Proc. Int. Conf. Bact. Wilt. G. L. Hartman and A. C. Hayward, eds. Kaoshiung, Taiwan.

Shekhawat, G. S., Chakrabarti, S. K., and Gadevar, A. V. 1992. Potato Bacterial Wilt in India. Tech. Bull. No. 38. Central Potato Research Institute. Shimla, India.

Singh, S., Singh, D. R., Kumar, K., and Birah, A. 2014. Eco-friendly management modules for bacterial wilt (Ralstonia solanacearum) of tomato for protected cultivation in a tropical Island ecosystem. Biol. Agric. Hortic. 30:219-227.

Spratt, B. G., Hanage, W. P., Li, B., Aanensen, D. M., and Feil, E. J. 2004 Displaying the relatedness among strains of bacterial species-The eBURST approach. FEMS Microbiol. Lett. 241:129-134.

Taghavi, M., Hayward, C., Sly, L. I., and Fegan, M. 1996. Analysis of the phylogenetic relationships of strains of Burkholderia solanacearum Pseudomonas syzygii and the blood disease bacterium of banana based on 16S rRNA gene sequences. Int. J. Syst. Bacteriol. 46:10-15.

Tamura, K., Nei, M., and Kumar, S. 2004. Prospects for inferring very large phylogenies by using the neighbor-joining method. Proc. Natl. Acad. Sci. USA 101:11030-11035.

Tamura, K., Stecher, G., Peterson, D., Filipski, A., and Kumar, S. 2013. Molecular Evolutionary Genetics Analysis version 6.0. Mol. Biol. Evol. 30:2725-2729.

Vasse, J., Frey, P., and Trigalet, A. 1995. Microscopic studies of intercellular infection and protoxylem invasion of tomato rots by $P$. solanacearum. Mol Plant-Microbe Interact. 8:241-251.

Wicker, E., Lefeuvre, P., de Cambiaire, J. C., Lemaire, C., Poussier, S., and Prior, P. 2012. Contrasting recombination patterns and demographic histories of the plant pathogen Ralstonia solanacearum inferred from MLSA. ISME J. 6: 961-974.

Yabuuchi, E., Kosako, Y., Yano, I., Hotta, H., and Nishiuchi, Y. 1995. Transfer of two Burkholderia and an Alcaligenes species to Ralstonia gen. nov.: Proposal of Ralstonia pickettii (Ralston, Palleroni and Doudoroff, 1973) comb. nov., Ralstonia solanacearum (Smith 1896) comb. nov. and Ralstonia eutropha (Davis 1969) comb. nov. Microbiol. Immunol. 39: 897-904. 